Article

\title{
An Inactivation Switch Enables Rhythms in a Neurospora Clock Model
}

\author{
Abhishek Upadhyay ${ }^{1, *(\mathbb{D}}$, Michael Brunner ${ }^{2}$ and Hanspeter Herzel ${ }^{1, *(1)}$ \\ 1 Institute for Theoretical Biology, Charité-Universitätsmedizin Berlin and Humboldt University of Berlin, \\ Philippstr. 13, 10115 Berlin, Germany \\ 2 Biochemistry Center, University of Heidelberg, Im Neuenheimer Feld 328, 69120 Heidelberg, Germany; \\ michael.brunner@bzh.uni-heidelberg.de \\ * Correspondence: abhishek.upadhyay@hu-berlin.de (A.U.); h.herzel@biologie.hu-berlin.de (H.H.); \\ Tel.: +30-2093-98402
}

Received: 04 April 2019; Accepted: 15 June 2019; Published: 19 June 2019

\begin{abstract}
Autonomous endogenous time-keeping is ubiquitous across many living organisms, known as the circadian clock when it has a period of about $24 \mathrm{~h}$. Interestingly, the fundamental design principle with a network of interconnected negative and positive feedback loops is conserved through evolution, although the molecular components differ. Filamentous fungus Neurospora crassa is a well-established chrono-genetics model organism to investigate the underlying mechanisms. The core negative feedback loop of the clock of Neurospora is composed of the transcription activator White Collar Complex (WCC) (heterodimer of WC1 and WC2) and the inhibitory element called FFC complex, which is made of FRQ (Frequency protein), FRH (Frequency interacting RNA Helicase) and CK1a (Casein kinase 1a). While exploring their temporal dynamics, we investigate how limit cycle oscillations arise and how molecular switches support self-sustained rhythms. We develop a mathematical model of 10 variables with 26 parameters to understand the interactions and feedback among WC1 and FFC elements in nuclear and cytoplasmic compartments. We performed control and bifurcation analysis to show that our novel model produces robust oscillations with a wild-type period of $22.5 \mathrm{~h}$. Our model reveals a switch between WC1-induced transcription and FFC-assisted inactivation of WC1. Using the new model, we also study the possible mechanisms of glucose compensation. A fairly simple model with just three nonlinearities helps to elucidate clock dynamics, revealing a mechanism of rhythms' production. The model can further be utilized to study entrainment and temperature compensation.
\end{abstract}

Keywords: circadian clock; mathematical modeling; molecular switch; Neurospora crassa; glucose compensation

\section{Introduction}

The Earth's rotation around its own axis gives rise to the 24-h day and night cycles. To anticipate these daily environmental changes in light and temperature, life in all its kingdoms has evolved a time-keeping molecular machinery [1-3]. In humans, disruption in the clock functioning due to jet lag, work shift, light at night, or other reasons increases the risk of diseases such as cancer, obesity, and sleep disorders [4-6].

In order to understand the basic clock mechanisms, we study a filamentous fungus, Neurospora crassa (N. crassa) [7]. Their natural habitats are soils, plants, trees, and food resources [8]. The ability of $N$. crassa to deconstruct and metabolize plant cell walls is crucial for environmental carbon and other nutrient cycling. There are also various potential biotechnological applications such as the production of biofuels. An example is the production of ethanol from xylose derived from plant 
dry matter biomass (lignocellulosic substrates). The xylan to ethanol pathway has been found to be clock regulated at each stage [9].

Mathematical modeling is useful to understand the Neurospora clock mechanism with multiple known feedback loops [10-15]. There are earlier models that considered only the core clock gene Frequency (FRQ) [10-12]. Recently, transcription factor White Collar-1 (WC1) has also been incorporated into the models [13-15]. In order to study glucose compensation, another feedback via Conidial Separation-1 (CSP1) [16] was included.

Figure 1 demonstrates the transcription-translation feedback loop, which consists of the inhibitory protein Frequency (FRQ), the activating transcription factor White Collar Complex (WCC), the FRQ stabilizer Frequency-interacting Helicase (FRH), and the Casein Kinase-1a (CK1a). Oscillations are based on delayed negative feedback. In Neurospora, clock gene frequency inhibits its own transcription after intermediate steps such as transcription, translation, dimerization, phosphorylations, and nuclear import. Moreover, stabilization of FRQ is governed by FRH and CK1a binding in forming the FFC complex. Later, FFC is involved in the inhibition of WCC-induced transcription [17-19].

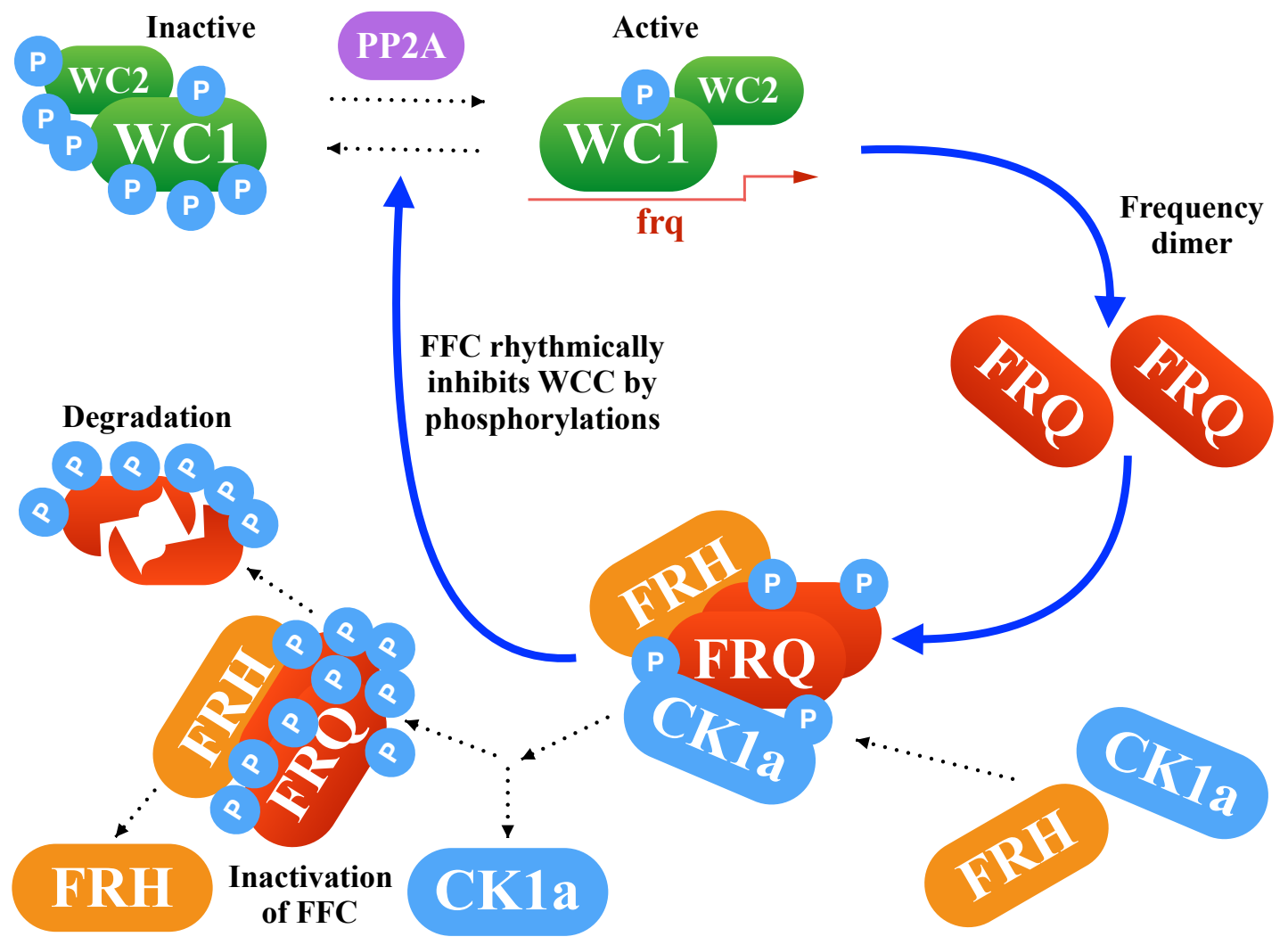

Figure 1. Core network of Neurospora's clock: The delayed negative feedback via FRQ is controlled by complex formations and phosphorylations.

The detailed mechanisms of the negative feedback are not well understood. For example, the inhibition of WCC via FFC might involve hyperphosphorylation, sequestration, and stoichiometric inhibition [20-24]. Moreover, it is not clear how the long delay is realized to obtain daily rhythms. In order to obtain self-sustained oscillations, nonlinearities are necessary.

The focus of our study is a deeper understanding of the underlying nonlinearities ("switches") and an analysis of the possible intrinsic mechanisms of glucose compensation in the Neurospora clock. Thus, our model addresses two general questions: (1) What are the underlying switch mechanisms? (2) How can a steady period be maintained for varying environmental conditions such as glucose 
availability? A comprehensive analysis of our mathematical model reveals that an inactivation switch allows self-sustained rhythms in the Neurospora clock. Our model also suggests in-built glucose compensation mechanisms.

\section{Results}

\subsection{Modeling the Core Clock Elements}

The negative feedback loop involves an implicit delay consisting of frq transcription and translation, FRQ dimerization, CK1a binding, nuclear import, formation of the FFC complex, and FFCn interaction with WC1n. A positive feedback involves the nuclear export of FFC supporting WC1c translation $[25,26]$. It is well known that FRQ and WCC are phosphorylated at many sites. Rhythmic phosphorylation influences complex formation and stability $[27,28]$. In our current model, we took these phosphorylations implicitly into account via appropriate rate constants.

Figure 2A shows the turnover of frq, wcc, and associated negative and positive feedback loops. Using primarily linear kinetic terms, this scheme can be directly translated into a system of Ordinary Differential Equations (ODEs) [29-32]. These equations are presented in Figure 2B. The 10 time-varying concentrations are denoted with brackets, and the 26 kinetic parameters are enumerated as a01, a02, a1, a2, ..., a21, n, K1, K2 (Appendix Figure A1).

\subsection{The Model Reproduces Self-Sustained Rhythms}

The basic scheme of the model is adapted from a previous study [15]. In order to study the role of FRH and FFC, we introduced three additional variables [FRQdCK1a]c, [FRQdCK1a]n, and [FFC]c (see Figure 2). The corresponding five parameters (a4, a6, a8, a10, a12) were taken from the proteins' half-lives in associated experiments $[27,33]$. In order to adapt expression levels, we increased the frq transcription rate (a1) and translation rate (a3, a15) (see Appendix Figure A1).

We kept most parameter values from the original model [15] (compare Appendix Figure A1). The remaining two parameters corresponding to the FRQdCK1a and FFC complex formation rates (a5 and a9) were adjusted to get a period of $22.5 \mathrm{~h}$ and robust limit cycle oscillations. Moreover, our model included a stronger positive feedback on cytoplasmic WC1 by FFC. We decreased the activation threshold from $\mathrm{K} 2=1$ in [15] to A2 = 0.3 in our model to strengthen the experimentally-verified positive feedback [25] (compare Appendix Figure A1).

Our resulting model consisted of 10 ODEs and 26 kinetic parameters. In order to get self-sustained rhythms, nonlinearities are necessary. Inspection of the equations in Figure 2B reveals that there were just three nonlinear terms: The transcription of the gene frq was modeled via a quadratic Hill function representing multiple WCC binding sites. The complex formation of FFC and WC1 was described by a bilinear term. The third nonlinearity modeled the positive feedback of the FFCc complex on WC1c translation as in the original model [15].

Figure 3 shows simulations of our model for the default parameters listed in Appendix Figure A1. The oscillations of frequency mRNA and protein (blue) were almost sinusoidal, whereas the levels of the inhibitory complex FFCn (red) and the transcription factor WC1n (green) displayed spike-like behavior. The resulting FFCnWC1n complex (yellow) exhibited even two peaks during one circadian cycle. This observation illustrates that nonlinearities can generate pronounced "harmonics", an example of ultradian rhythms. Harmonics have been described in large-scale transcription profiles in mouse $[34,35]$ and recently also in Neurospora [36]. The final graph in Figure 3 represents the transcription of the frq gene. It is evident that there was a sharp ON/OFF switch of transcription. In a later section, we will relate this temporal switch to FFC-assisted inactivation of the transcription factor WC1. 


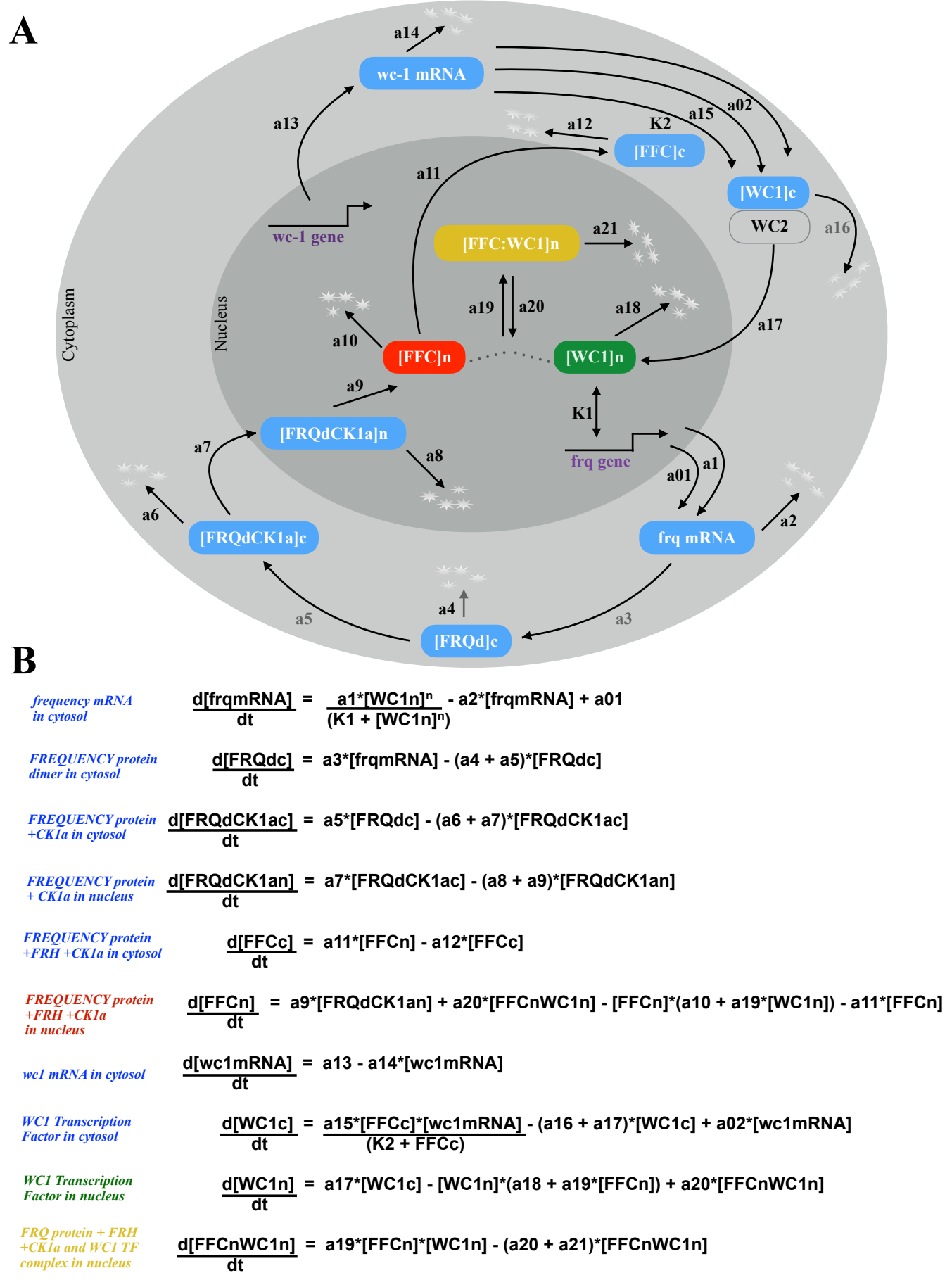

Figure 2. Neurospora circadian clock model: The wiring diagram of the model shows compartmentalization into nucleus and cytoplasm, turnover of frq and wc1 colored in blue, complex formations, and nuclear translocation. The core components of the inactivation switch are marked by green, red, and yellow throughout the paper (A). Ordinary differential equations with 10 variables and 26 parameters $(\mathbf{B})$.

\subsection{Bifurcation Analysis of Our Model}

The available kinetic data were not sufficient to determine all model parameters precisely. Moreover, external conditions can induce parameter variations. Consequently, we varied all 26 parameters in a comprehensive manner to explore the robustness of the model and to evaluate the role of the different kinetic terms along the lines of previous studies [37,38]. 
The self-sustained oscillations were obtained in wide ranges of parameters (see Figures 4 and A2). Amplitudes and periods varied smoothly with most parameters. The onset of oscillations occurred in most cases via a Hopf bifurcation, a transition from damped to self-sustained rhythms. Close to Hopf bifurcations, we found large amplitude variations, but weaker dependencies of the period on the parameters.
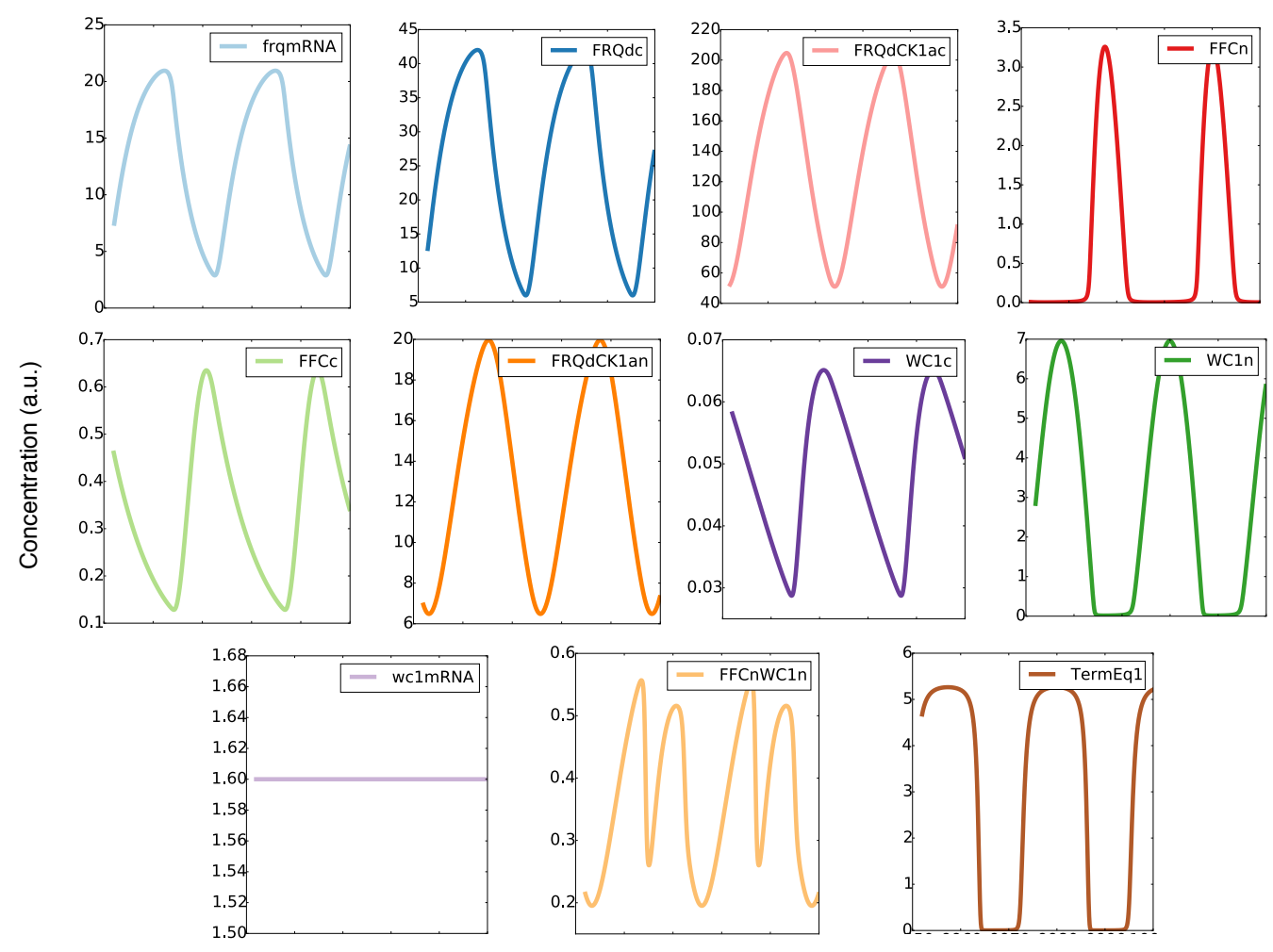

Figure 3. Simulated time series: There are sinusoidal and spike-like waveforms, harmonics, and a temporal switch (see the text).

Interestingly, for three parameters, we observed hard onsets of oscillations (compare Appendix Figure A2), i.e., the amplitude jumped abruptly. Such bifurcations were characterized by hysteresis and co-existing attractors [39-41] (see the basins of attractors in Appendix Figure A3). The details of these phenomena are presented in Appendix Figures A2 and A3.

Nonlinearities are necessary to obtain limit cycle oscillations. As discussed above, our model exhibited just three nonlinear terms. In order to check their relevance, we replaced the terms by their mean (termed "clamping" in [42,43]) or by a linearized kinetics. Interestingly, for two of the nonlinearities, the oscillations persisted. This implies that the dimerization and the positive feedback were not essential to obtain self-sustained oscillations. Thus, the only essential nonlinearity in our model was the Hill function describing frq transcription. Details of the detection of essential nonlinearities are provided in the Supplementary Information (Appendix Figure A4).

In summary, the developed model exhibited robust self-sustained oscillations with just a single nonlinearity and a fairly small Hill coefficient $n=2$.

In earlier models, artificially high Hill coefficients have been used [11,12]. As in [15], we used a biologically-plausible small Hill coefficient [44]. Since there are two distinct binding sites for WCC in the frq promoter [22], a Hill coefficient of $n=2$ was justified [45].

We can exploit now our model to discuss mutants, to analyze the underlying transcriptional switch, and to explore possible glucose compensation mechanisms. 

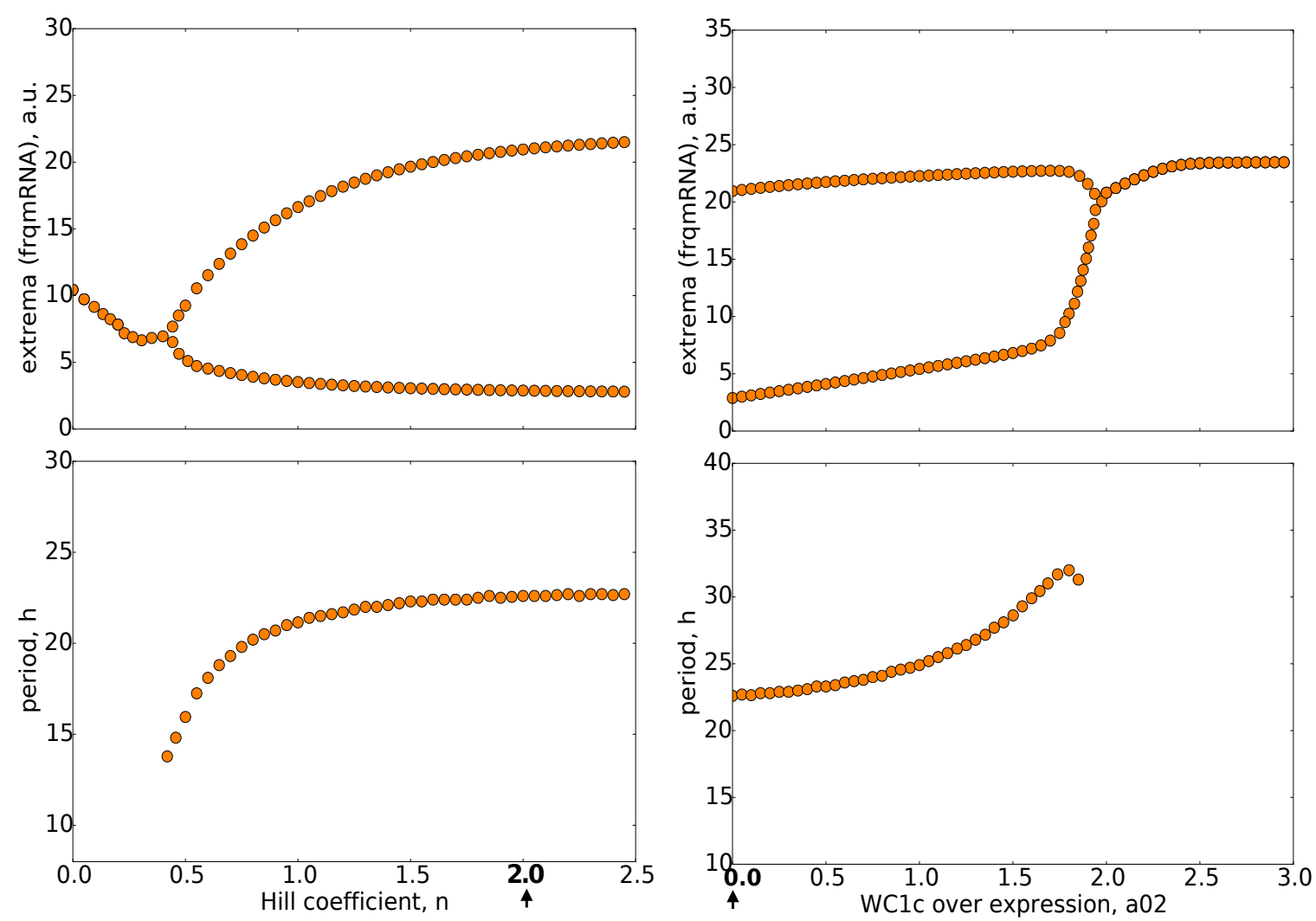

Figure 4. Bifurcation diagrams: The upper graphs show the maxima and minima of oscillations for varying parameters $\mathrm{n}$ (Hill coefficient) and a02 (WC1c overexpression). The lower graphs depict the corresponding periods. It turns out that oscillations persist for Hill coefficient $\mathrm{n}$ between 0.5 and 2.5, whereas overexpression of WC1 (a02) can terminate rhythms. Default parameter values are marked by bold numbers and arrows.

\subsection{Our Model Reproduced Clock Mutants}

$N$. crassa has become a model organism in chronobiology since a band mutation in the ras-1 pathway leads to an overt periodic conidiation phenotype. A growth front of rhythmic conidiation and mycelium in so-called race tubes (solid culture) and gene expressions from bioluminescence signals using a frq-promoter luciferase reporter assay helped visualizing a period of about $22.5 \mathrm{~h}[46,47]$. These techniques also allowed the identification of point mutations in the frq gene with altered period lengths. For example, the frq7 mutation stabilizes FRQ, leading to a longer period of about $29 \mathrm{~h}$ [46].

Table 1 lists several mutant phenotypes and associated experimental findings regarding protein stability. If we adapted our model rate constants accordingly, we could simulate the phenotypes of wild-type (frq+) and shorter and longer period mutants (frq1 and frq7), as shown in Appendix Figure A5. Moreover, our model also reproduced the behavior of an FWD-1 knockout experiment demonstrating that complete turnover of FRQ was not required for the clock to run [48] (see Appendix Figure A5). This implies that the model was faithful to the experimental results, which is a good indication for any mathematical model. 
Table 1. Modeling Neurospora clock mutants: A list of selected mutants and their properties (simulations in Appendix Figure A5).

\begin{tabular}{|c|c|c|c|c|c|c|c|c|c|}
\hline $\begin{array}{l}\text { Genotype } \\
\text { (Name) }\end{array}$ & $\begin{array}{l}\text { Genotype } \\
\text { (Mutation) }\end{array}$ & $\begin{array}{c}\text { Period } \\
\text { (Race Tube) }\end{array}$ & $\begin{array}{l}\text { Phenotype } \\
\text { (Race Tube) }\end{array}$ & $\begin{array}{l}\text { Core Clock Genes } \\
\text { (Luciferase } \\
\text { Reporter) }\end{array}$ & $\begin{array}{l}\text { Temperature } \\
\text { Compensation }\end{array}$ & $\begin{array}{c}\text { Glucose } \\
\text { Compensation }\end{array}$ & $\begin{array}{l}\text { Proposed } \\
\text { Effects } \\
\text { Experimentally }\end{array}$ & $\begin{array}{l}\text { Model } \\
\text { Representation } \\
\text { of Effects }\end{array}$ & References \\
\hline $\begin{array}{c}f r q^{+} \\
\text {wild-type }\end{array}$ & $\begin{array}{c}\text { ras1 } \\
\text { band }\end{array}$ & $22.5 \mathrm{~h}$ & rhythmic & oscillate & normal & normal & {$[\mathrm{FRQ}] \mathrm{n}<[\mathrm{WC} 1] \mathrm{n}$} & $\begin{array}{c}\text { default parameters } \\
(\mathrm{a} 7=0.05, \mathrm{a} 8=0.34 \\
\mathrm{a} 10=0.10)\end{array}$ & [46] \\
\hline$f r q^{1}$ & $\begin{array}{l}\text { Gly-Ser } \\
\text { G482S }\end{array}$ & $16.5 \mathrm{~h}$ & rhythmic & oscillate & normal & normal & $\begin{array}{l}\text { [FRQ]n of } f r q^{1}>o f f r q^{+} \\
\text {decreased FRQ stability, } \\
\text { and [FRQ]n }>[\text { WC1]n }\end{array}$ & $\begin{array}{c}\text { faster nuclear import rate } \\
\text { a7 }=2.5 \text { and increased FRQ } \\
\text { degradation rate a } 8=0.68\end{array}$ & [46] \\
\hline$f r q^{7}$ & $\begin{array}{l}\text { Gly-Asp } \\
\text { G433D }\end{array}$ & $29 \mathrm{~h}$ & rhythmic & oscillate & partially lost & & $\begin{array}{c}\text { increased FRQ amplitude, } \\
\text { increased FRQ stability, } \\
\text { and approximately [FRQ]n = [WC1]n }\end{array}$ & $\begin{array}{c}\text { decreased FRQ degradation } \\
\text { rate } \mathrm{a} 8=0.17\end{array}$ & {$[46,49]$} \\
\hline fwd1 & $\begin{array}{c}f w d 1^{R I P} \\
\text { COP9-signalosome }\end{array}$ & undefined & arrhythmic & oscillate & & & incomplete turnover of FRQ & $\begin{array}{c}\text { no FFCn } \\
\text { degradation rate a10 }=0\end{array}$ & [48] \\
\hline
\end{tabular}




\subsection{An Inactivation-Switch Allows Self-Sustained Oscillation}

It is widely known that molecular switches support limit cycle oscillations [50-53]. Moreover, the switch-like waveforms in the time series of our model discussed above indicate a switch. However, the biological mechanism of such a switch is not immediately evident.

Multiple mechanisms have been discussed that allow switch-like behavior. For example, cooperativity [54,55], zero-order ultrasensitivity [56], and multiple phosphorylations [57,58] can lead to quite steep input-output relationships [59]. Furthermore, sequestration [60] and positive feedback [61] can generate bistable switches [62-65].

Our model shows that expression of FFCn was mostly smaller than WC1n. Only a small fraction of WC1n was bound in the complex FFCWC1n (yellow line in Figure 5A). Therefore, a pure sequestration of WC1n by FFCn is unlikely. However, an inspection of the rate constants (Appendix Figure A1) revealed the underlying switch mechanism: The degradation rate a18 of the active WC1n was quite low. If the levels of FFCn grew around Time Point 10 in Figure 5A, fast binding of FFCn to WC1n (a19 > a20) allowed the sudden deactivation of WC1n (a21 > a18). A switch between active transcription to FFC-assisted fast inactivation served as the basic mechanism. Note, that these steps required neither high Hill coefficients, nor positive feedback, as in many other oscillator models [12,66].
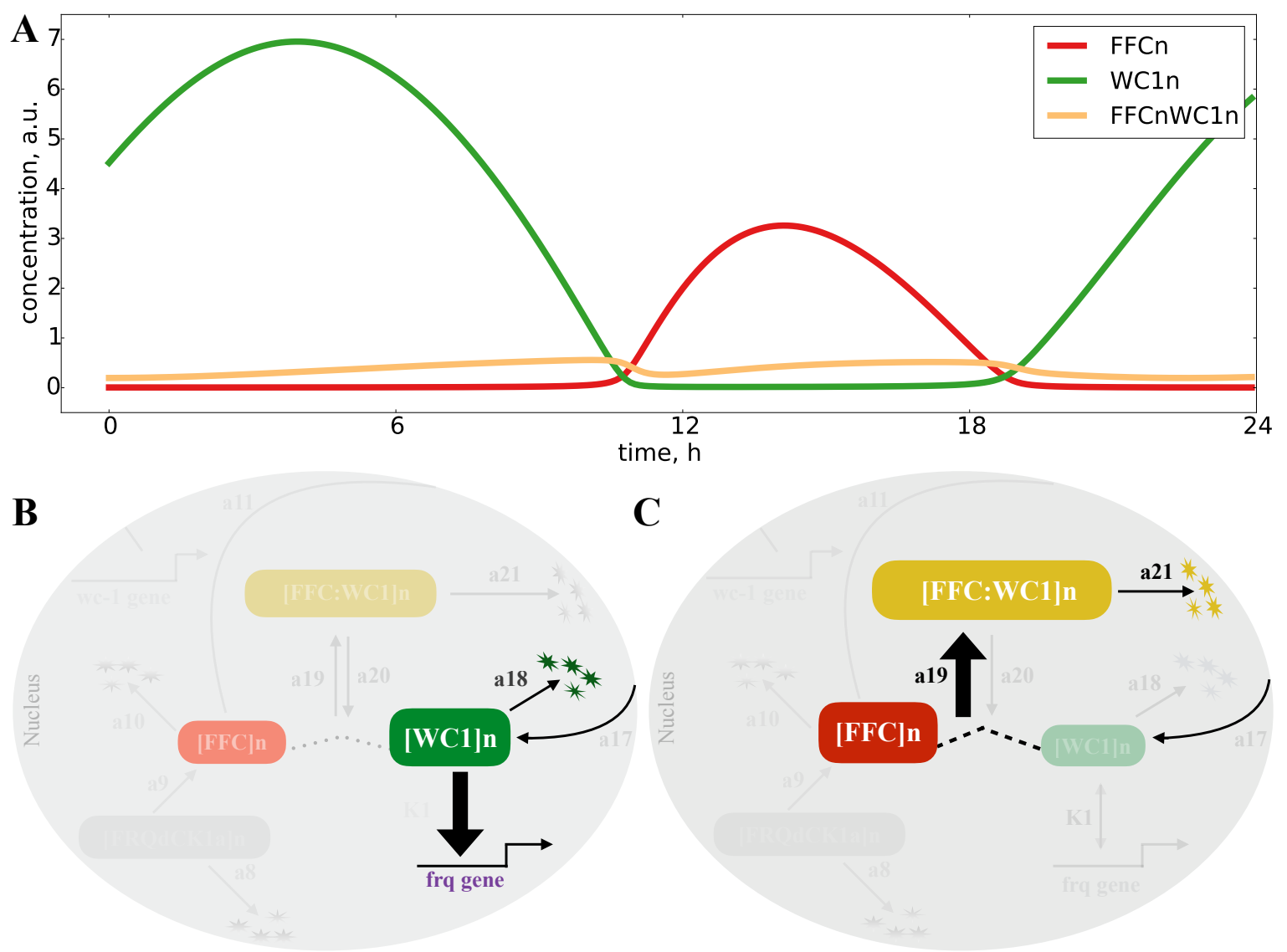

Figure 5. Inactivation switch in the Neurospora clock model: The FFCn levels (red line) are most of the time lower than the WC1n levels (green line), and only a small fraction of WC1n is bound to FFCn (yellow line) (see A). Below, we distinguish on and off phases. (B) points to an active WC1 (the thick line indicates strong binding to frq promoter) with a small degradation rate a18 (thin line). (C) illustrates the off state with FFC-assisted inactivation of WC1. Here, we have a strong binding of FFC to WC1 (a19 > a20) and fast degradation (a21 > a18). 


\subsection{Sensitivity Analysis Pointed to Inherent Glucose Compensation Mechanisms}

Circadian clocks, in general, have to be robust against environmental fluctuations. Therefore, they utilize compensation mechanisms against the changes in temperature and nutrients (glucose), where changes in these environmental signals do not affect the overall clock period. There are suggested temperature compensation mechanisms [67-69] and glucose compensation via CSP1 [16].

Here, we study the possibilities for glucose compensation without an extra feedback CSP1 [16] using our model. We assumed that high glucose facilitates transcription and translation of FRQ and WC1. Simulations showed that faster transcription and translation rates $(\mathrm{a} 1, \mathrm{a} 3)$ of frequency increased the oscillatory period (compare Figure 6). This was consistent with the data from the mammalian circadian clock [70,71]. With a systematic sensitivity analysis (Figure 6), we searched for putative compensation mechanisms. A promising candidate was the helicase FRH, since it has a dual role in the network: degradation of nascent mRNAs and formation of the FFC complex [27,72].

To quantify period changes for varying the parameters, we calculated the control coefficients by quantifying the sensitivity of the system. In Figure 6, we show a comprehensive control analysis of our model along the lines of [37,45,73]. All parameters were changed by \pm 10 percent, and the corresponding period changes were extracted from the simulations. A positive period control coefficient of 0.5 implies that a 10 percent parameter increase induced a period lengthening by five percent, i.e., about $1 \mathrm{~h}$. Our analysis confirmed the well-known feature that faster degradation of frequency leads to shorter periods [74], as discussed above for the $f r q^{1}$ mutant (see the yellow bars associated with increasing parameters a2, a4, a6, a8, and a10).

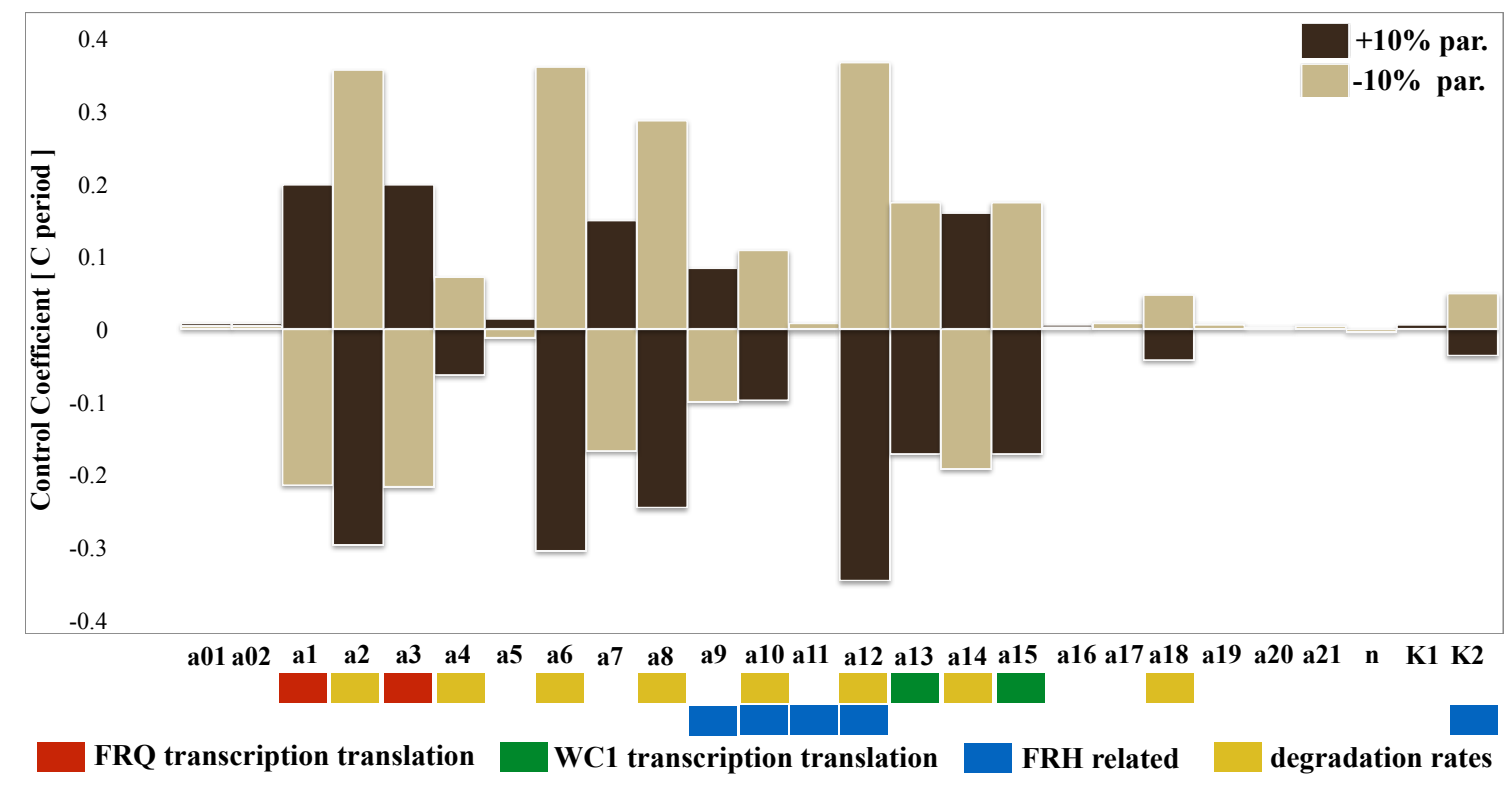

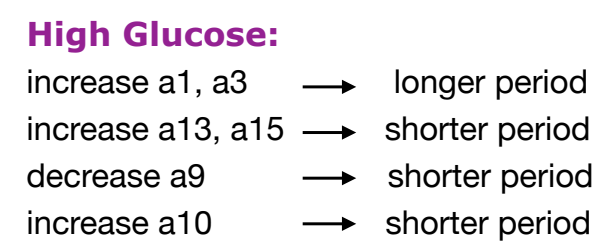

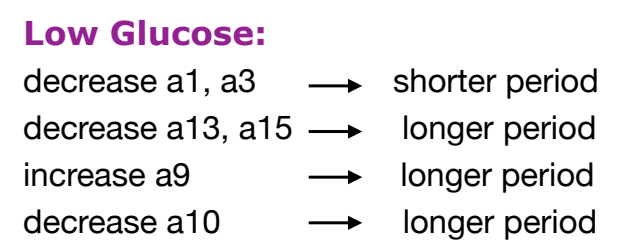

Low Glucose:

decrease a1, a3 $\longrightarrow$ shorter period

decrease a13, a15 $\longrightarrow$ longer period

decrease a10 $\rightarrow$ longer period

Figure 6. Sensitivity analysis: All parameters were changed by \pm 10 percent, and the resulting periods were calculated. Positive and negative period control coefficients indicate period lengthening and shortening, respectively. 
Now, we discuss possible mechanisms to get compensation of high glucose levels. The period increase via faster frequency production (a1, a3) could be compensated by faster WC1 production $(\mathrm{a} 13, \mathrm{a} 15)$ since the corresponding control coefficients have opposite signs. In order to study the dual role of FRH, we marked in Figure 6 the FRH-related parameters blue (a9, a10, a11, a12, and K2). It turned out that the dual role of FRH can indeed serve as a compensation mechanism as follows: Enhanced transcription due to high glucose sequesters the helicase FRH. This leads to a slower assembly of FFC (a smaller a9 value) and less stabilization of FFC (larger a10 value). According to Figure 6, these effects can compensate the period increase due to an increased frequency production. Interestingly, the glucose compensation through the dual role of FRH was lost if we canceled the positive feedback of FFCc on WC1c translation via clamping (Appendix Figure A6).

\section{Discussion}

Understanding circadian clocks quantitatively helps to explore their functional significance in different organisms [75]. In mammals, a functional clock can help to prevent diseases such as cancer, obesity, and depression [4]. To reveal the basic mechanisms of the underlying gene-regulatory network (see Figure 1), Neurospora crassa has been established as a useful model organism [3].

Mathematical modeling complements experimental studies and can help to uncover the underlying design principles [12,32]. A Transcriptional-Translational Feedback Loop (TTFL) serves as the generator of self-sustained oscillations with a period of about a day, but quantitative details of these delayed negative feedback [76] and supporting molecular switches [77] are debated.

The required delay of at least $6 \mathrm{~h}$ [78] is associated with gene expression, phosphorylation, nuclear translocation, complex formations, and epigenetic regulations $[79,80]$. In addition to appropriate delays, limit cycle oscillations require nonlinearities such as molecular switches [37], as studied extensively in cell proliferation and differentiation [50,62].

To explore the temporal dynamics of the Neurospora clock, we developed a mathematical model (Figure 2) that reproduces basic features of wild-type rhythms and selected mutants (Table 1). Simulations revealed spike-like waveforms and a temporal transcriptional switch (Figure 3). Appendix Figure A7A shows that harmonic waveforms and a sharp temporal switch were less pronounced in the original model [15]. There was an earlier oscillation onset in our model (compare Figures 4 and A7B). Systematic clamping and linearization revealed that there was just one essential nonlinearity with a Hill coefficient of $n=2$. This raises the question of how the ON/OFF switch of the frequency gene was generated without explicit ultrasensitivity or bistability.

As illustrated in Figure 5, we found sharp transitions between active transcription with slow turnover of WC1 and fast FFC-assisted inactivation of WC1. Related protein inactivation switches have been discussed in recent studies [81-84].

Our model can also be exploited to study the compensations of environmental fluctuations. It has been found experimentally that the Neurospora clock keeps its period almost constant at varying temperatures and glucose concentrations $[67,68]$. In a previous study, an auxiliary transcriptional feedback loop via CSP1 was postulated for glucose compensation [16].

Sensitivity analysis of our model (Figure 6) suggested in-built mechanisms without additional feedbacks. High levels of glucose enhance gene expression. Our model indicated that higher levels of core clock genes increased the period, as found experimentally in Neurospora $[17,18]$ and in mammals [70]. Interestingly, enhanced WC1 levels decreased the period (compare Figure 6). This counter-regulation constitutes a first putative compensation mechanism.

Another glucose compensation mechanism is based on the dual role of FRH. This protein serves as an RNA helicase and as a stabilizer of the FFC complex [27,72]. Since at high glucose conditions, many more mRNAs are transcribed, FRH is partially sequestered. This implies that the FFC complex is destabilized, leading to a shortening of the period. This effect can compensate the increased period induced by enhanced transcription. Interestingly, this compensation was diminished if we turned off the positive feedback via WC1 translation [25]. This finding points to a possible role of this additional 
feedback regulation. Note that this feedback was quite weak in the original model [15]. We decreased the activation threshold $\mathrm{K} 2$ for $\mathrm{WC} 1$ translation to strengthen the experimentally-verified positive feedback $[18,25]$.

In summary, we modified a model by extending the negative loop via FRH complexes and by strengthening the positive feedback. Both modifications contributed to the robustness of the model (Figure 4), the inactivation switch (Figure 5), and intrinsic glucose compensation (Figure 6). Our proposed mathematical model with 10 dynamic variables and 26 kinetic parameters reproduced many experimentally-known features. A comprehensive analysis of the model revealed some unexpected results. It turns out that there was just a single nonlinearity essential for self-sustained oscillations. The switch-like behavior of the model arose from a novel inactivation switch based of WC1 inactivation assisted by the FFC complex. This finding suggests that forthcoming experiments should be oriented towards the detailed mechanisms of WC1-FFC interactions.

Another result concerns the compensation of environmental perturbations. Sensitivity analysis of our model suggested putative in-built mechanisms to achieve glucose compensation. First, expression of the WC1 gene could counteract the effects of frequency expression on the period. Another mechanism points to possible roles of FRH and the positive feedback. Sequestration of FRH via increasing mRNA transcription leads to a destabilization of the FFC complex, which can compensate period changes in the presence of the positive feedback.

Even though our model was not quantitative in any detail, the comparison of simulations with experimental data can stimulate future investigations. The combination of a delayed negative feedback with an inactivation switch is a robust design principle that could be relevant also in other oscillatory systems such as cell cycle dynamics [85], redox oscillations [86], or somite formation [87,88].

\title{
4. Materials and Methods
}

All the simulations were performed using codes on a Spyder Python 3.4 platform. Ordinary differential equations were written into codes using the SciPy odeint library. Matplotlib library was used to generate figures. XPP-Auto was used to reproduce the bifurcation diagrams generated by Python. Codes are available upon request.

Author Contributions: Conceptualization by M.B. and H.H.; methodology by A.U. and H.H.; software by A.U.; validation by A.U. and H.H.; formal analysis by A.U.; investigation, A.U. and H.H.; resources by H.H.; data curation by M.B.; writing — original draft preparation by A.U. and H.H.; writing-review and editing, A.U., H.H. and M.B.; visualization by A.U. and H.H.; supervision by M.B. and H.H.; project administration by M.B. and H.H.; funding acquisition by M.B. and H.H.

Funding: This research was funded by the Deutsche Forschungsgemeinschaft (DFG, German Research Foundation), Project Number 278001972-TRR 186. We also acknowledge support from the German Research Foundation (DFG) and the Open Access Publication Fund of Charite-Universitätsmedizin Berlin.

Acknowledgments: The authors are thankful to J. Patrick Pett, Christoph Schmal, Daniela Marzoll, Axel Diernfellner, Norbert Gyongyosi, Marta del Olmo, Philipp Burt, and Katharina Baum for fruitful discussions. We thank the anonymous reviewers for their helpful suggestions.

Conflicts of Interest: The authors declare no conflict of interest.

\author{
Abbreviations \\ The following abbreviations are used in this manuscript: \\ N. crassa Neurospora crassa \\ frq Frequency gene \\ FRQ Frequency protein \\ WCC White Collar Complex Protein \\ WC1 White Collar-1 Protein
}




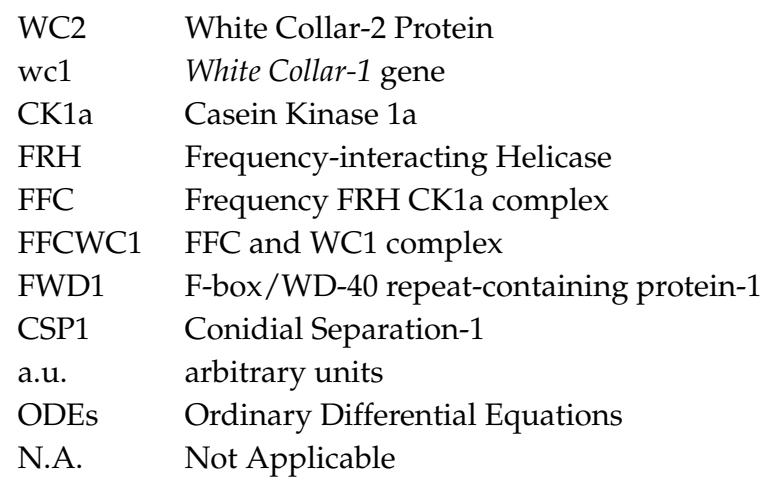

\section{Appendix A}

\begin{tabular}{|c|c|c|}
\hline Our model parameters (value in a.u.) & representation into biological processes & Hong model parameters (a.u.) [15] \\
\hline $\mathrm{a} 01=0$ & frqmRNA over expression & $\mathrm{k} 01=0$ \\
\hline $\mathbf{a 0 2}=\mathbf{0}$ & WC1c over expression & $\mathrm{k} 02=0$ \\
\hline $\mathrm{a} 1=5.4$ & frq transcription rate & $\mathrm{k} 1=1.8$ \\
\hline $\mathrm{a} 2=0.23$ & frqmRNA degradation rate & $\mathrm{k} 4=0.23$ \\
\hline $\mathrm{a} 3=5.4$ & FRQdc translation rate & $\mathrm{k} 2=1.8$ \\
\hline $\mathrm{a} 4=0.69$ & FRQdc degradation rate & $\mathrm{k} 5=0.27$ \\
\hline $\mathbf{a 5}=\mathbf{2}$ & FRQdCK1ac transition rate & N.A. \\
\hline $\mathrm{a} 6=0.34$ & FRQdCK1ac degradation rate & N.A. \\
\hline $\mathrm{a} 7=\mathbf{0 . 0 5}$ & FRQdCK1an nucleus import rate & $\mathrm{k} 3=0.05$ \\
\hline $\mathrm{a} 8=0.34$ & FRQdCK1an degradation rate & N.A. \\
\hline a9 $=0.15$ & FFCn transition rate & N.A. \\
\hline $\mathrm{a} 10=0.11$ & FFCn degradation rate & $\mathrm{k} 6=0.07$ \\
\hline a11 $=0.05$ & FFCc cyto import rate & N.A. \\
\hline $\mathrm{a} 12=0.11$ & FFCc degradation rate & N.A. \\
\hline $\mathrm{a} 13=0.16$ & wc1 transcription rate & $\mathrm{k} 7=0.16$ \\
\hline $\mathrm{a} 14=0.1$ & wc1mRNA degradation rate & $\mathrm{k} 10=0.1$ \\
\hline $\mathbf{a} 15=2.4$ & WC1c translation rate & $\mathrm{k} 8=0.8$ \\
\hline $\mathrm{a} 16=0.05$ & WC1c degradation rate & $\mathrm{k} 11=0.05$ \\
\hline $\mathbf{a} 17=40$ & WC1n nucleus import rate & $\mathrm{k} 9=40$ \\
\hline $\mathrm{a} 18=0.02$ & WC1n degradation rate & $\mathrm{k} 12=0.02$ \\
\hline $\mathbf{a} 19=\mathbf{5 0}$ & FFCnWC1n complex association rate & $\mathrm{k} 13=50$ \\
\hline $\mathbf{a} 20=1$ & FFCnWC1n complex dissociation rate & $\mathrm{k} 14=1$ \\
\hline $\mathbf{a} 21=5$ & FFCnWC1n complex degradation rate & $\mathrm{k} 15=5$ \\
\hline $\mathbf{n}=\mathbf{2}$ & Hill coefficient & $\mathrm{n}=2$ \\
\hline $\mathrm{K} 1=\mathbf{1 . 2 5}$ & WCC dissociation constant to frq promoter & $\mathrm{K}=1.25$ \\
\hline $\mathrm{K} 2=\mathbf{0 . 3}$ & WC1c accumulation by FFCc & $\mathrm{K} 2=1$ \\
\hline
\end{tabular}

Figure A1. Kinetic parameters: A list of rate constants and their associated biological processes. 

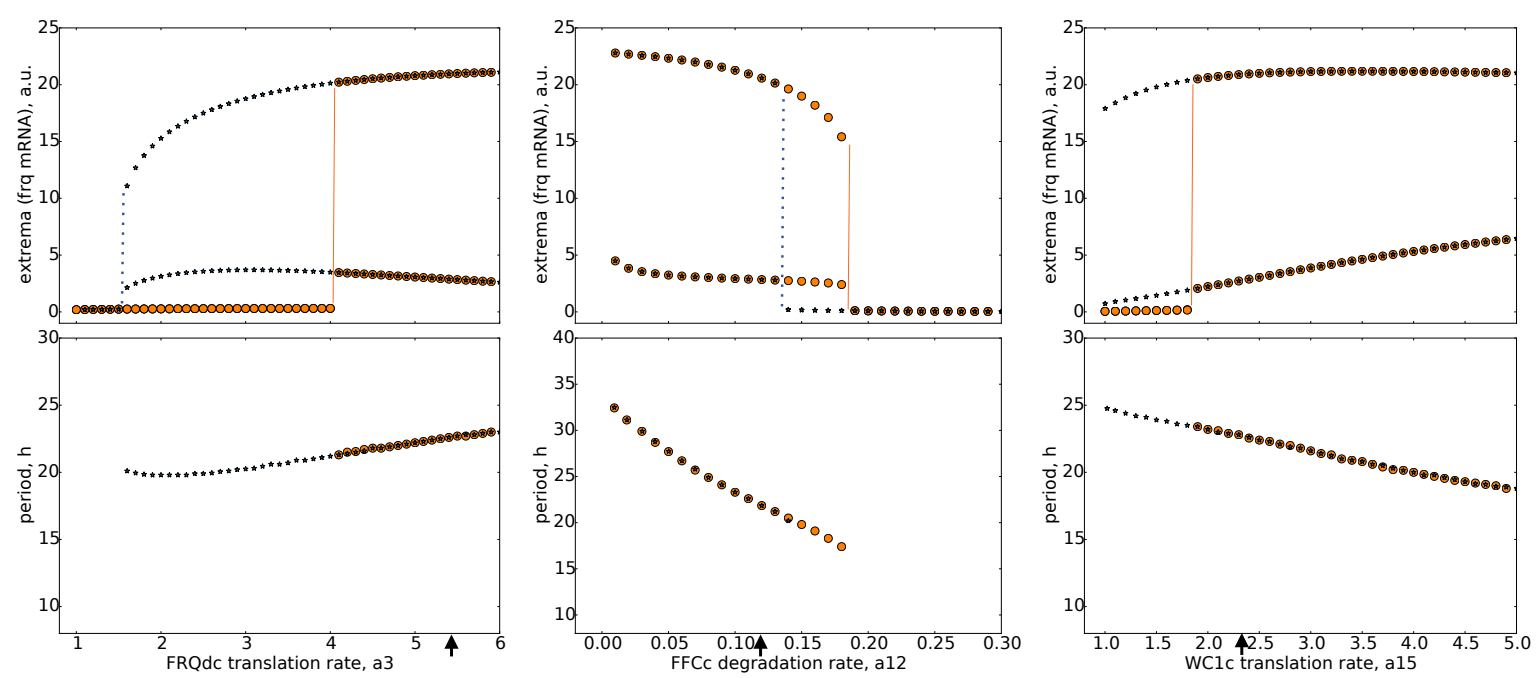

Figure A2. Co-existence of attractors: Bifurcation analysis of three parameters shows the co-existence of the limit cycle and steady state while the parameter is slowly varied. The values for increasing parameters are marked by orange circles. Decreasing parameters correspond to blue stars. Red lines mark jumps between steady states (low frq values) to limit cycle oscillations. The associated periods are given in the lower graphs. Default parameter values are marked by arrows.

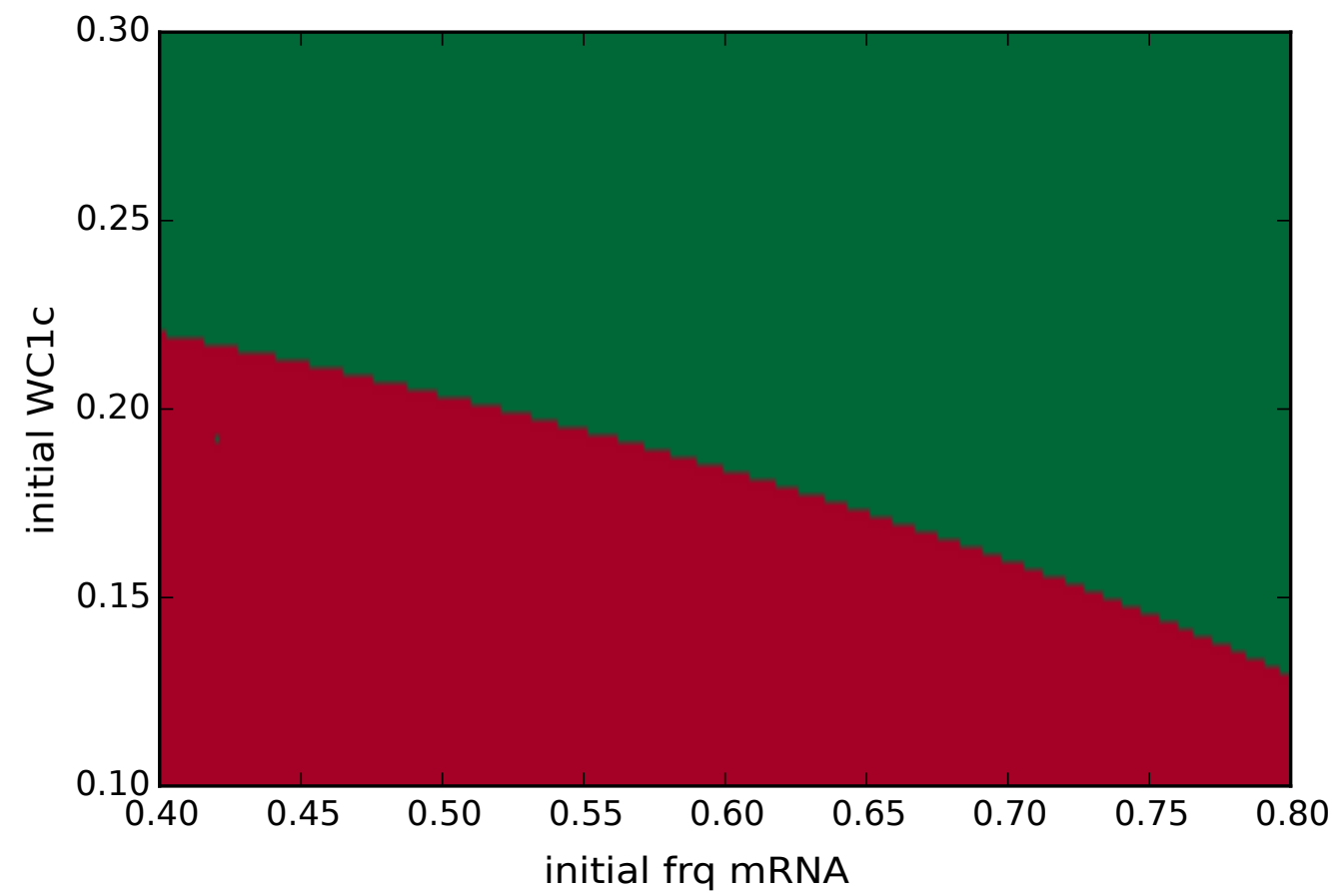

Figure A3. Basins of attractors: Coexisting attractors shown in Figure A2 imply distinct basins of attraction (here, a3 =3). Small initial values of frq and wc1 (red area) approach the steady state, whereas initial conditions in green approach the limit cycle. The initial conditions of the other variables were zero. 

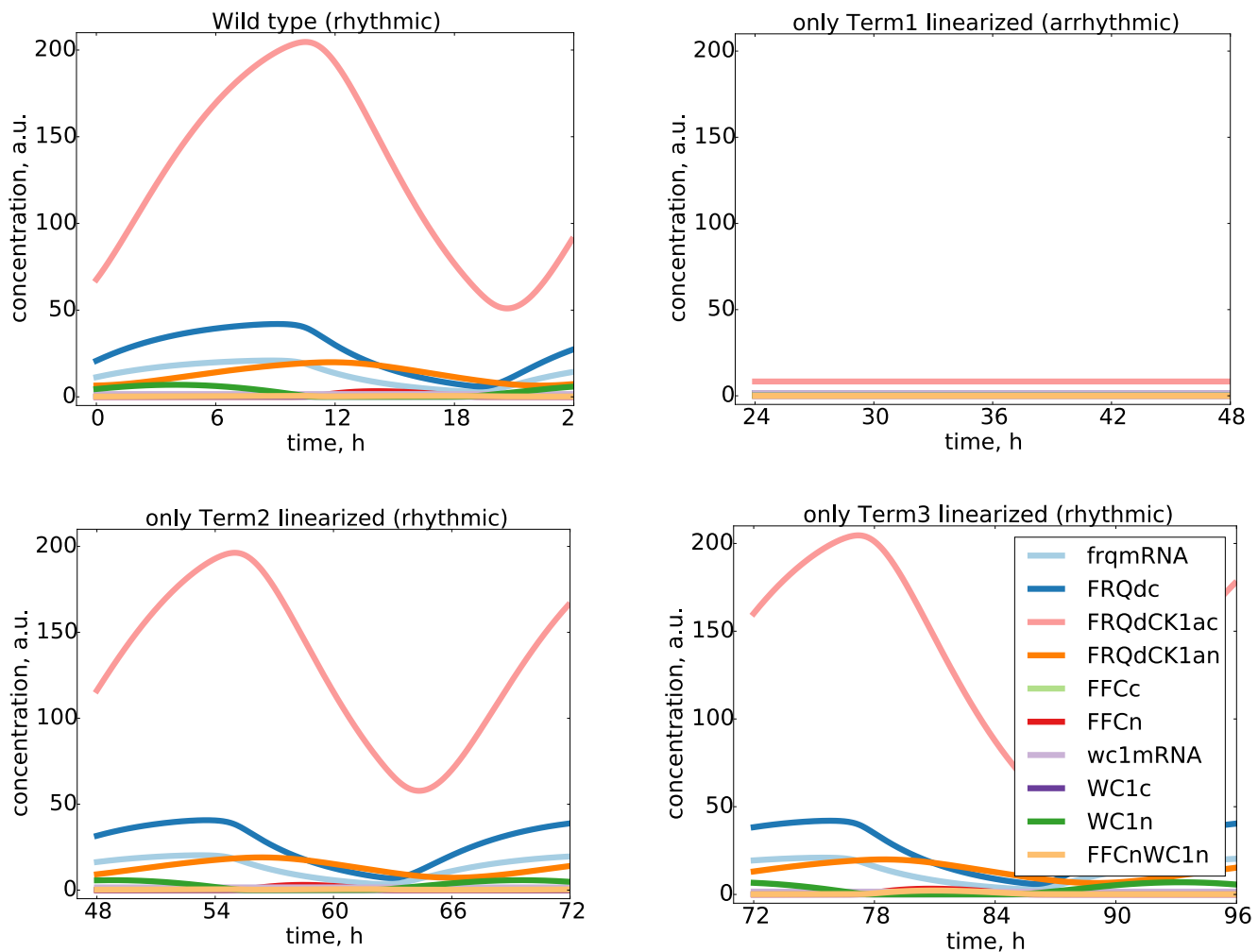

Figure A4. Essential and non-essential nonlinearities in the model: We linearized all three nonlinear terms and found that the Hill function of frq production (Term1) was essential, whereas the positive feedback nonlinearity (Term2) and the bilinear dimerization (Term3) were not essential since linearizations kept the rhythmicity.
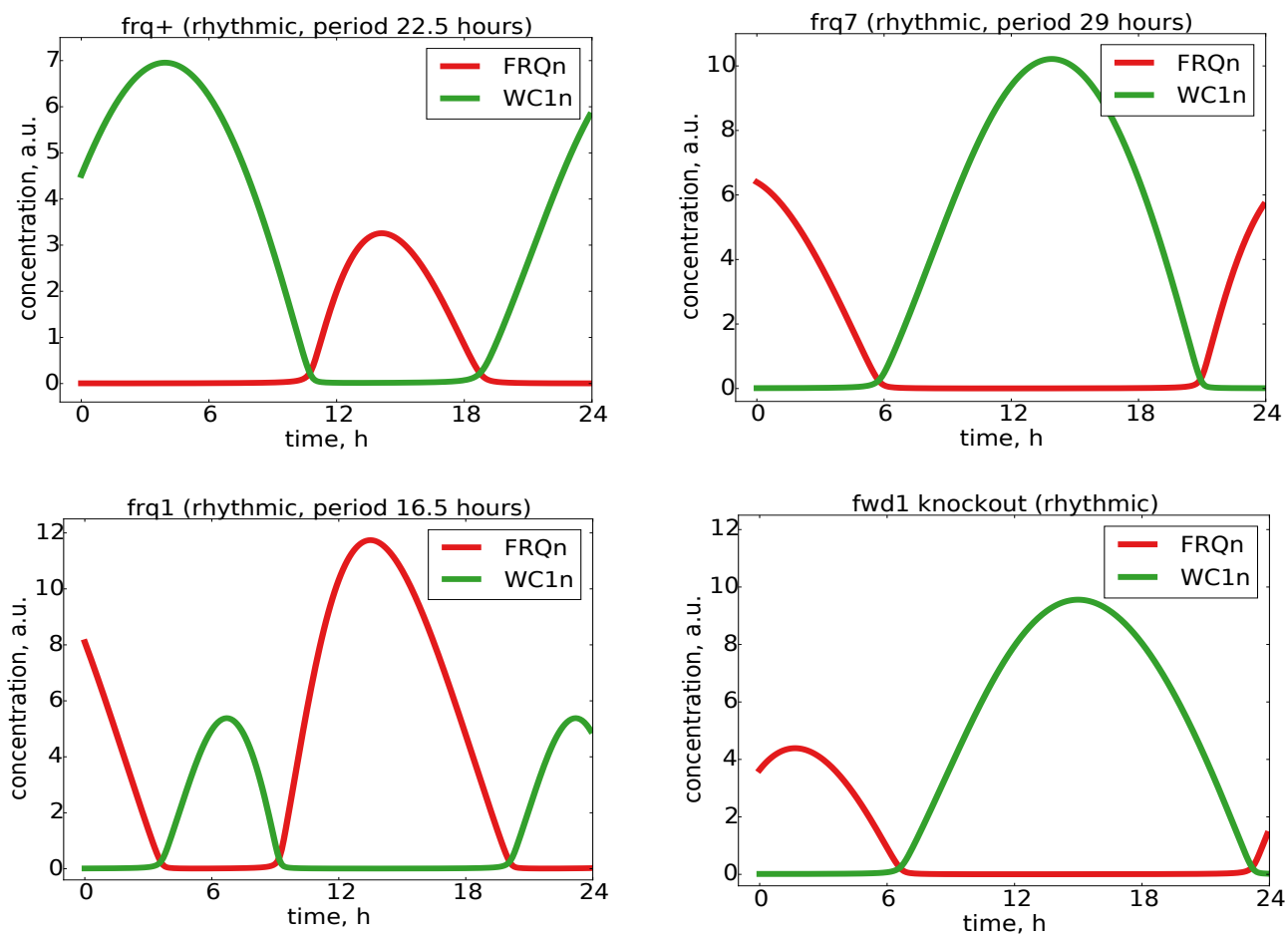

Figure A5. Mutant simulations: Several experimentally-observed mutants were also reproduced by our model. The corresponding modified parameters are given in Table 1. 


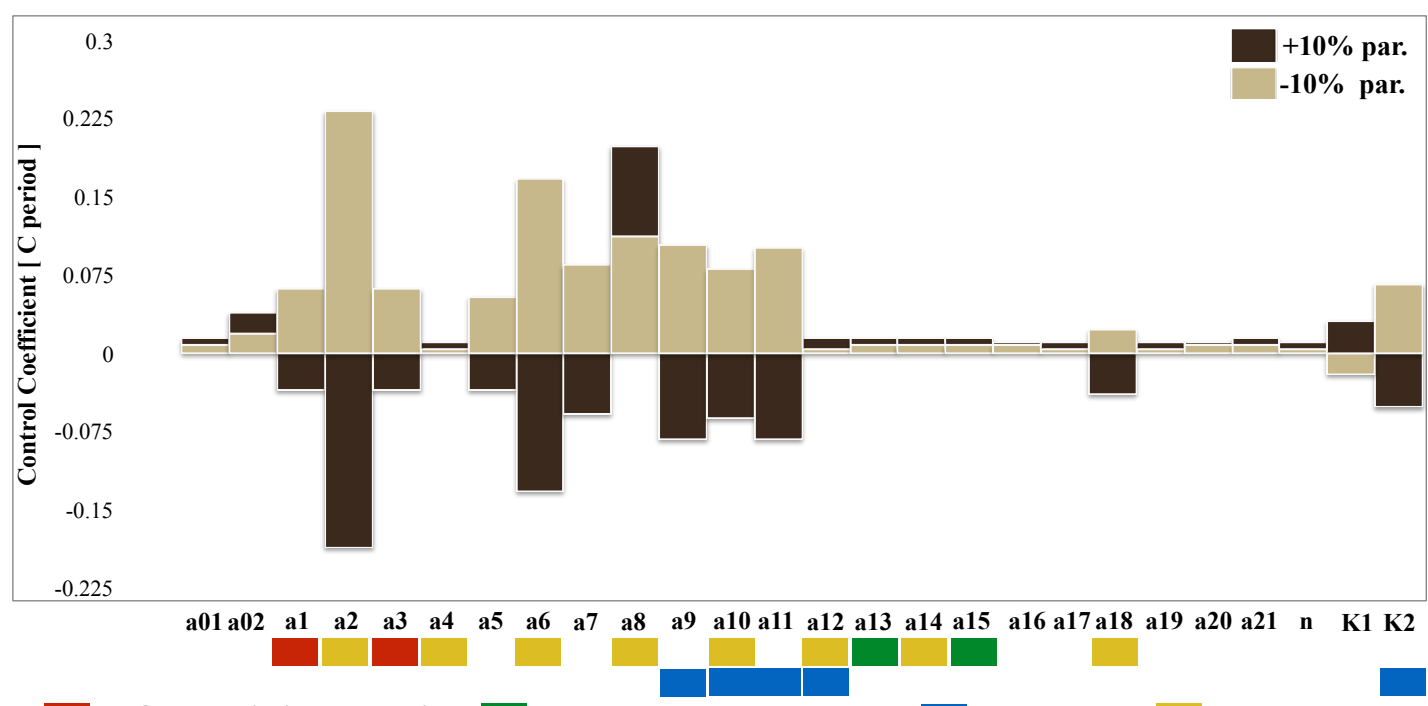

FRQ transcription translation

WC1 transcription translation

FRH related

degradation rates

Figure A6. Sensitivity analysis after clamping the positive feedback: All parameters were changed by \pm 10 percent, and the resulting periods were calculated. Positive and negative period control coefficients indicate period lengthening and shortening, respectively (compare Figure 6).

A
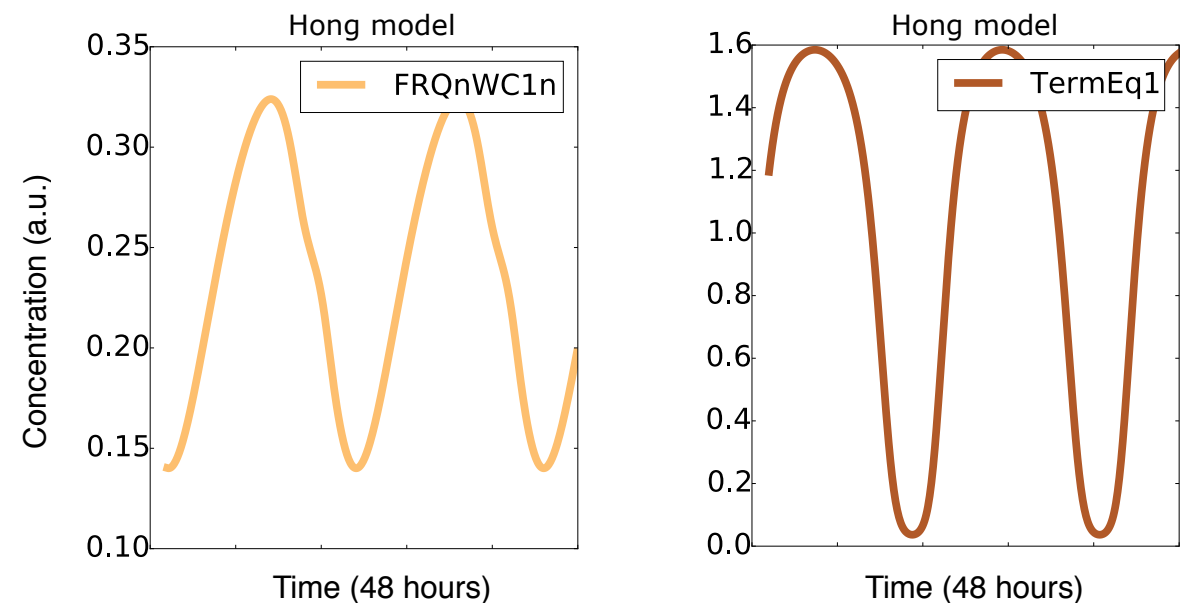

B

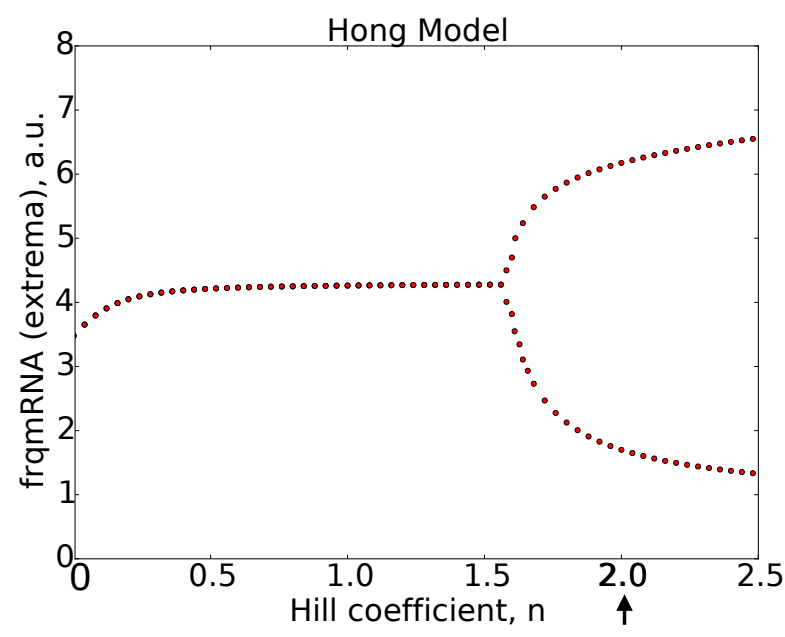

Figure A7. Comparisons with the Hong model [15]: (A) There are no double peaks of the FRQnWC1n complex and a less pronounced switch (compare Figure 3). (B) The Hopf bifurcation is shifted to higher Hill coefficients (compare Figure 4). 


\section{References}

1. Wever, R. Zum Mechanismus der biologischen 24-Stunden-Periodik. Kybernetik 1963, 2, $214-231$.

2. Konopka, R.J.; Benzer, S. Clock mutants of Drosophila melanogaster. PNAS 1971, 68, 2112-2116. [CrossRef] [PubMed]

3. Dunlap, J.; Loros, J.; DeCoursey, P. Chronobiology: Biological Timekeeping; Sinauer Associates: Sunderland, MA, USA, 2004.

4. Fuhr, L.; Abreu, M.; Pett, P.; Relógio, A. Circadian systems biology: When time matters. Comput. Struct. Biotechnol. J. 2015, 13, 417-426. [CrossRef] [PubMed]

5. Vanselow, K.; Vanselow, J.T.; Westermark, P.O.; Reischl, S.; Maier, B.; Korte, T.; Herrmann, A.; Herzel, H.; Schlosser, A.; Kramer, A. Differential effects of PER2 phosphorylation: Molecular basis for the human familial advanced sleep phase syndrome (FASPS). Genes Dev. 2006, 20, 2660-2672. [CrossRef] [PubMed]

6. Relógio, A.; Thomas, P.; Medina-Pérez, P.; Reischl, S.; Bervoets, S.; Gloc, E.; Riemer, P.; Mang-Fatehi, S.; Maier, B.; Schäfer, R.; et al. Ras-Mediated Deregulation of the Circadian Clock in Cancer. PLoS Genet. 2014, 10, e1004338. [CrossRef] [PubMed]

7. Froehlich, A.; Pregueiro, A.; Lee, K.; Denault, D. The molecular workings of the Neurospora biological clock. In Molecular Clocks and Light Signalling; John Wiley: New York, NY, USA, 2003; pp. 184-202.

8. Koritala, B.; Lee, K. Natural variation of the circadian clock in Neurospora. Adv. Genet. 2017, 99, 1-37. [PubMed]

9. Hurley, J.; Jankowski, M.; De los Santos, H.; Crowell, A.; Fordyce, S.; Zucker, J.; Kumar, N.; Purvine, S.; Robinson, E.; Shukla, A.; et al. Circadian proteomic analysis uncovers mechanisms of post-transcriptional regulation in metabolic pathways. Cell Syst. 2018, 7, 613-626. [CrossRef] [PubMed]

10. Lakin-Thomas, P.L.; Brody, S.; Coté, G.G. Amplitude model for the effects of mutations and temperature on period and phase resetting of the Neurospora circadian oscillator. J. Biol. Rhythm. 1991, 6, 281-297. [CrossRef]

11. Ruoff, P.; Rensing, L. The temperature-compensated goodwin model simulates many circadian clock properties. J. Theor. Biol. 1996, 179, 275-285. [CrossRef]

12. Leloup, J.C.; Gonze, D.; Goldbeter, A. Limit Cycle Models for Circadian Rhythms Based on Transcriptional Regulation in Drosophila and Neurospora. J. Biol. Rhythm. 1999, 14, 433-448. [CrossRef]

13. Ruoff, P.; Vinsjevik, M.; Monnerjahn, C.; Rensing, L. The goodwin model: Simulating the effect of light pulses on the circadian sporulation rhythm of Neurospora crassa. J. Theor. Biol. 2001, 209, 29-42. [CrossRef]

14. François, P. A model for the Neurospora circadian clock. Biophys. J. 2005, 88, 2369-2383. [CrossRef] [PubMed]

15. Hong, C.I.; Jolma, I.W.; Loros, J.J.; Dunlap, J.C.; Ruoff, P. Simulating dark expressions and interactions of frq and wc-1 in the Neurospora circadian clock. Biophys. J. 2008, 94, 1221-1232. [CrossRef] [PubMed]

16. Dovzhenok, A.A.; Baek, M.; Lim, S.; Hong, C.I. Mathematical modeling and validation of glucose compensation of the Neurospora circadian clock. Biophys. J. 2015, 108, 1830-1839. [CrossRef] [PubMed]

17. Brunner, M.; Káldi, K. Interlocked feedback loops of the circadian clock of Neurospora crassa. Mol. Microbiol. 2008, 68, 255-262. [CrossRef]

18. Lee, K.; Loros, J.J.; Dunlap, J.C. Interconnected feedback loops in the Neurospora circadian system. Science 2000, 289, 107-110. [CrossRef] [PubMed]

19. Merrow, M.; Brunner, M.; Roenneberg, T. Assignment of circadian function for the Neurospora clock gene frequency. Nature 1999, 399, 584. [CrossRef] [PubMed]

20. Schafmeier, T.; Haase, A.; Káldi, K.; Scholz, J.; Fuchs, M.; Brunner, M. Transcriptional feedback of Neurospora circadian clock gene by phosphorylation-dependent inactivation of its transcription factor. Cell 2005, 122, 235-246. [CrossRef] [PubMed]

21. He, Q.; Cha, J.; He, Q.; Lee, H.C.; Yang, Y.; Liu, Y. CKI and CKII mediate the FREQUENCY-dependent phosphorylation of the WHITE COLLAR complex to close the Neurospora circadian negative feedback loop. Genes Dev. 2006, 20, 2552-2565. [CrossRef]

22. Froehlich, A.; Loros, J.; Dunlap, J. Rhythmic binding of a WHITE COLLAR-containing complex to the frequency promoter is inhibited by FREQUENCY. Proc. Natl. Acad. Sci. USA 2003, 100, 5914-5919. [CrossRef]

23. Menet, J.S.; Abruzzi, K.C.; Desrochers, J.; Rodriguez, J.; Rosbash, M. Dynamic PER repression mechanisms in the Drosophila circadian clock: From on-DNA to off-DNA. Genes Dev. 2010, 24, 358-367. [CrossRef] [PubMed] 
24. Kim, J.K.; Forger, D.B. A mechanism for robust circadian timekeeping via stoichiometric balance. Mol. Syst. Biol. 2012, 8, 1-14. [CrossRef] [PubMed]

25. Schafmeier, T.; Káldi, K.; Diernfellner, A.; Mohr, C.; Brunner, M. Phosphorylation-dependent maturation of Neurospora circadian clock protein from a nuclear repressor toward a cytoplasmic activator. Genes Dev. 2006, 20, 297-306. [CrossRef] [PubMed]

26. Diernfellner, A.; Querfurth, C.; Salazar, C.; Höfer, T.; Brunner, M. Phosphorylation modulates rapid nucleocytoplasmic shuttling and cytoplasmic accumulation of Neurospora clock protein FRQ on a circadian time scale. Genes Dev. 2009, 23, 2192-2200. [CrossRef] [PubMed]

27. Lauinger, L.; Diernfellner, A.; Falk, S.; Brunner, M. The RNA helicase FRH is an ATP-dependent regulator of CK1a in the circadian clock of Neurospora crassa. Nat. Commun. 2014, 5, 3598. [CrossRef] [PubMed]

28. Diernfellner, A.; Schafmeier, T. Phosphorylations: Making the Neurosporacrassa circadian clock tick. FEBS Lett. 2011, 585, 1461-1466. [CrossRef] [PubMed]

29. Ingalls, B. Mathematical Modeling in Systems Biology: An Introduction; MIT Press: Cambridge, MA, USA, 2013.

30. Kim, J.K. Mathematical Modeling and Analysis of Cellular Clocks. Ph.D. Thesis, University of Michigan, Ann Arbor, MI, USA, 2013.

31. Klipp, E.; Liebermeister, W.; Wierling, C.; Kowald, A. Systems Biology: A Textbook, 2nd ed.; Wiley-Blackwell: Hoboken, NJ, USA, 2016.

32. Alon, U. An Introduction to Systems Biology: Design Principles of Biological Circuits; Chapman and Hall/CRC: Boca Raton, FL, USA, 2006.

33. Sancar, G.; Sancar, C.; Brunner, M. Metabolic compensation of the Neurospora clock by a glucose-dependent feedback of the circadian repressor CSP1 on the core oscillator. Genes Dev. 2012, 26, 2435-2442. [CrossRef]

34. Hughes, M.E.; DiTacchio, L.; Hayes, K.R.; Vollmers, C.; Pulivarthy, S.; Baggs, J.E.; Panda, S.; Hogenesch, J.B. Harmonics of Circadian Gene Transcription in Mammals. PLoS Genet. 2009, 5, e1000442. [CrossRef]

35. Westermark, P.O.; Herzel, H. Mechanism for $12 \mathrm{Hr}$ Rhythm Generation by the Circadian Clock. Cell Rep. 2013, 3, 1228-1238. [CrossRef]

36. Ananthasubramaniam, B.; Diernfellner, A.; Brunner, M.; Herzel, H. Ultradian Rhythms in the Transcriptome of Neurospora crassa. iScience 2018, 9, 475-486. [CrossRef]

37. Wolf, J.; Becker-Weimann, S.; Heinrich, R.; Wolf, J.; Heinrich, R. Analysing the robustness of cellular rhythms. Syst. Biol. 2005, 2, 35-41. [CrossRef]

38. Schmal, C.; Leloup, J.C.; Gonze, D. Modeling and simulating the Arabidopsis thaliana circadian clock using XPP-AUTO. In Plant Circadian Networks: MethodsE Protocols; Humana Press: New York, NY, USA, 2014; Volume 1158, pp. 203-208. [CrossRef]

39. Mergell, P.; Herzel, H.; Wittenberg, T.; Tigges, M.; Eysholdt, U. Phonation onset: Vocal fold modeling and high-speed glottography. J. Acoust. Soc. Am. 1998, 104, 464-470. [CrossRef]

40. Steinecke, I.; Herzel, H. Bifurcations in an asymmetric vocal-fold model. J. Acoust. Soc. Am. 1995, 97, 1874-1884. [CrossRef] [PubMed]

41. Li, W.; Krishna, S.; Pigolotti, S.; Mitarai, N.; Jensen, M. Switching between oscillations and homeostasis in competing negative and positive feedback motifs. J. Theor. Biol. 2012, 307, 205-210. [CrossRef]

42. Pett, J.P.; Korencic, A.; Wesener, F.; Kramer, A.; Herzel, H. Feedback Loops of the Mammalian Circadian Clock Constitute Repressilator. PLoS Comput. Biol. 2016, 12, e1005266. [CrossRef] [PubMed]

43. Pett, J.; Kondoff, M.; Bordyugov, G.; Kramer, A.; Herzel, H. Co-existing feedback loops generate tissue-specific circadian rhythms. Life Sci. Alliance 2018, 1, e201800078. [CrossRef] [PubMed]

44. Kim, J.K. Protein sequestration versus Hill-type repression in circadian clock models. IET Syst. Biol. 2016, 10, 125-135. [CrossRef]

45. Korenčič, A.; Bordyugov, G.; Košir, R.; Rozman, D.; Goličnik, M.; Herzel, H. The Interplay of cis-Regulatory Elements Rules Circadian Rhythms in Mouse Liver. PLoS ONE 2012, 7, e46835. [CrossRef]

46. Loros, J.J.; Dunlap, J.C. Genetic and molecular analysis of circadian rhythms in Neurospora. Annu. Rev. Physiol. 2001, 63, 757-794. [CrossRef]

47. Larrondo, L.F.; Colot, H.V.; Baker, C.L.; Loros, J.J.; Dunlap, J.C. Fungal functional genomics: Tunable knockout-knock-in expression and tagging strategies. Eukaryot. Cell 2009, 8, 800-804. [CrossRef]

48. Larrondo, L.F.; Olivares-Yañez, C.; Baker, C.L.; Loros, J.J.; Dunlap, J.C. Decoupling circadian clock protein turnover from circadian period determination. Science 2015, 347, 1257277. [CrossRef] [PubMed] 
49. Lakin-Thomas, P.L.; Coté, G.G.; Brody, S. Circadian rhythms in neurospora crassa: Biochemistry and genetics. Crit. Rev. Microbiol. 1990, 17, 365-416. [CrossRef] [PubMed]

50. Tyson, J.J.; Albert, R.; Goldbeter, A.; Ruoff, P.; Sible, J. Biological switches and clocks. J. R. Soc. Interface 2008, 5, S1-S8. [CrossRef]

51. Schmal, C.; Reimann, P.; Staiger, D. A Circadian Clock-Regulated Toggle Switch Explains AtGRP7 and AtGRP8 Oscillations in Arabidopsis thaliana. PLoS Comput. Biol. 2013, 9, e1002986. [CrossRef] [PubMed]

52. Tyson, J.; Chen, K.; Novak, B. Sniffers, buzzers, toggles and blinkers: Dynamics of regulatory and signaling pathways in the cell. Curr. Opin. Cell Biol. 2003, 15, 221-231. [CrossRef]

53. Dalchau, N.; Szép, G.; Hernansaiz-Ballesteros, R.; Barnes, C.P.; Cardelli, L.; Phillips, A.; Csikász-Nagy, A. Computing with biological switches and clocks. Nat. Comput. 2018, 17, 761-779. [CrossRef] [PubMed]

54. Hodgkin, A.L.; Huxley, A.F. A quantitative description of membrane current and its application to conduction and excitation in nerve. J. Physiol. 1952, 117, 500-544. [CrossRef]

55. Hill, A.V. Proceedings supplement: The possible effects of the aggregation of the molecules of haemoglobin on its dissociation curves. J. Physiol. 1910, 40, iv-vii.

56. Goldbeter, A.; Koshland, D.E. Zero-order Ultrasensitivity in Interconvertible Enzyme Systems. In Control of Metabolic Processes; Springer: Boston, MA, USA, 1990; pp. 173-182. [CrossRef]

57. Salazar, C.; Höfer, T. Multisite protein phosphorylation-From molecular mechanisms to kinetic models. FEBS J. 2009, 276, 3177-3198. [CrossRef]

58. Legewie, S.; Blüthgen, N.; Herzel, H. Quantitative analysis of ultrasensitive responses. FEBS J. 2005, 272, 4071-4079. [CrossRef]

59. Ferrell, J.E.; Ha, S.H. Ultrasensitivity part I: Michaelian responses and zero-order ultrasensitivity. Trends Biochem. Sci. 2014, 39, 496-503. [CrossRef] [PubMed]

60. Legewie, S.; Blüthgen, N.; Herzel, H. Mathematical Modeling Identifies Inhibitors of Apoptosis as Mediators of Positive Feedback and Bistability. PLoS Comput. Biol. 2006, 2, e120. [CrossRef] [PubMed]

61. Novak, B.; Tyson, J. Design principles of biochemical oscillators. Nat. Rev. Mol. Cell Biol. 2008, 9, 981-990. [CrossRef]

62. Ferrell, J.E.; Ha, S.H. Ultrasensitivity part III: Cascades, bistable switches, and oscillators. Trends Biochem. Sci. 2014, 39, 612-618. [CrossRef] [PubMed]

63. Blüthgen, N.; Legewie, S.; Herzel, H.; Kholodenko, B. Mechanisms Generating Ultrasensitivity, Bistability, and Oscillations in Signal Transduction. In Introduction to Systems Biology; Humana Press: Totowa, NJ, USA, 2007; pp. 282-299. [CrossRef]

64. Mutzel, V.; Okamoto, I.; Dunkel, I.; Saitou, M.; Giorgetti, L.; Heard, E.; Schulz, E.G. A symmetric toggle switch explains the onset of random X inactivation in different mammals. Nat. Struct. Biol. 2019, 26, 350-360. [CrossRef]

65. Gérard, C.; Gonze, D.; Goldbeter, A. Revisiting a skeleton model for the mammalian cell cycle: From bistability to Cdk oscillations and cellular heterogeneity. J. Theor. Biol. 2019, 461, 276-290. [CrossRef]

66. Goldbeter, A. Biochemical Oscillations and Cellular Rhythms: The Molecular Bases of Periodic and Chaotic Behaviour; Cambridge University Press: Cambridge, UK, 1997.

67. Ruoff, P.; Loros, J.J.; Dunlap, J.C. The relationship between FRQ-protein stability and temperature compensation in the Neurospora circadian clock. Proc. Natl. Acad. Sci. USA 2005, 102, 17681-17686. [CrossRef]

68. Diernfellner, A.; Colot, H.V.; Dintsis, O.; Loros, J.J.; Dunlap, J.C.; Brunner, M. Long and short isoforms of Neurospora clock protein FRQ support temperature-compensated circadian rhythms. FEBS Lett. 2007, 581, 5759-5764. [CrossRef]

69. François, P.; Despierre, N.; Siggia, E.D. Adaptive temperature compensation in circadian oscillations. PLoS Comput. Biol. 2012, 8, e1002585. [CrossRef]

70. Dibner, C.; Sage, D.; Unser, M.; Bauer, C.; D’Eysmond, T.; Naef, F.; Schibler, U. Circadian gene expression is resilient to large fluctuations in overall transcription rates. EMBO J. 2009, 28, 123-134. [CrossRef]

71. Relógio, A.; Westermark, P.O.; Wallach, T.; Schellenberg, K.; Kramer, A.; Herzel, H. Tuning the mammalian circadian clock: Robust synergy of two loops. PLoS Comput. Biol. 2011, 7, e1002309. [CrossRef] [PubMed]

72. Hurley, J.M.; Larrondo, L.F.; Loros, J.J.; Dunlap, J.C. Conserved RNA helicase FRH acts nonenzymatically to support the intrinsically disordered neurospora clock protein FRQ. Mol. Cell 2013, 52, 832-843. [CrossRef] [PubMed] 
73. Baum, K.; Politi, A.Z.; Kofahl, B.; Steuer, R.; Wolf, J. Feedback, Mass Conservation and Reaction Kinetics Impact the Robustness of Cellular Oscillations. PLoS Comput. Biol. 2016, 12, e1005298. [CrossRef] [PubMed]

74. Ruoff, P.; Vinsjevik, M.; Monnerjahn, C.; Rensing, L. The Goodwin oscillator: On the importance of degradation reactions in the circadian clock. J. Biol. Rhythm. 1999, 14, 469-479. [CrossRef] [PubMed]

75. Granada, A.E.; Herzel, H.; Kramer, A.; Abraham, U. Information Transfer in the Mammalian Circadian Clock. In Information-and Communication Theory in Molecular Biology; Springer: Berlin/Heidelberg, Germany, 2018; pp. 247-257.

76. Hardin, P.E.; Hall, J.C.; Rosbash, M. Feedback of the Drosophila period gene product on circadian cycling of its messenger RNA levels. Nature 1990, 343, 536-540. [CrossRef] [PubMed]

77. Ananthasubramaniam, B.; Herzel, H. Positive feedback promotes oscillations in negative feedback loops. PLoS ONE 2014, 9, e104761. [CrossRef]

78. Bordyugov, G.; Westermark, P.O.; Korenčič, A.; Bernard, S.; Herzel, H. Mathematical Modeling in Chronobiology. In Circadian Clocks; Springer: Berlin/Heidelberg, Germany, 2013; pp. 335-357. [CrossRef]

79. Wang, B.; Kettenbach, A.N.; Gerber, S.A.; Loros, J.J.; Dunlap, J.C. Neurospora WC-1 Recruits SWI/SNF to Remodel frequency and Initiate a Circadian Cycle. PLoS Genet. 2014, 10, e1004599. [CrossRef]

80. Steffen, P.A.; Fonseca, J.P.; Ringrose, L. Epigenetics meets mathematics: Towards a quantitative understanding of chromatin biology. BioEssays 2012, 34, 901-913. [CrossRef]

81. Querfurth, C.; Diernfellner, A.; Gin, E.; Malzahn, E.; Höfer, T.; Brunner, M. Circadian conformational change of the Neurospora clock protein FREQUENCY triggered by clustered hyperphosphorylation of a basic domain. Mol. Cell 2011, 43, 713-722. [CrossRef]

82. Menet, J.; Rosbash, M. A new twist on clock protein phosphorylation: A conformational change leads to protein degradation. Mol. Cell 2011, 43, 695-697. [CrossRef]

83. Narasimamurthy, R.; Hunt, S.; Lu, Y.; Fustin, J.; Okamura, H.; Partch, C.; Forger, D.; Kim, J.; Virshup, D. CK1 $\delta / \epsilon$ protein kinase primes the PER2 circadian phosphoswitch. Proc. Natl. Acad. Sci. USA 2018, 115, 5986-5991. [CrossRef] [PubMed]

84. Zhou, M.; Kim, J.; Eng, G.; Forger, D.; Virshup, D. A Period2 phosphoswitch regulates and temperature compensates circadian period. Mol. Cell 2015, 60, 77-88. [CrossRef] [PubMed]

85. Tyson, J.; Csikasz-Nagy, A.; Novak, B. The dynamics of cell cycle regulation. BioEssays 2002, 24, $1095-1109$. [CrossRef] [PubMed]

86. del Olmo, M.; Kramer, A.; Herzel, H. A Robust Model for Circadian Redox Oscillations. Int. J. Mol. Sci. 2019, 20, 2368. [CrossRef] [PubMed]

87. Baker, R.E.; Schnell, S.; Maini, P.K. A clock and wavefront mechanism for somite formation. Dev. Biol. 2006, 293, 116-126. [CrossRef] [PubMed]

88. Aulehla, A.; Pourquie, O. Oscillating signaling pathways during embryonic development. Curr. Opin. Cell Biol. 2008, 20, 632-637. [CrossRef]

(c) 2019 by the authors. Licensee MDPI, Basel, Switzerland. This article is an open access article distributed under the terms and conditions of the Creative Commons Attribution (CC BY) license (http:/ / creativecommons.org/licenses/by/4.0/). 